\title{
Mefluidide effect on Caucasian bluestem leaves, stems, for- age yield, and quality
}

LARRY M. WHITE

\section{Abstract}

'Caucasian'bluestem [Bothriochloa caucasica (Trin.) C.E. Hubb.] provides high quality forage during early summer but growth of floral stems causes a rapid decline in forage quality. In 1985 and 1986 mefluidide [N-(2,4-dimethyl-5-\{[(trifluromethyl)sulfonyl] amino\}-phenyl)acetamide], a growth regulator, was applied to Caucasian in late May, early June, and mid June at $0.00,0.28,0.56$, and $0.84 \mathrm{~kg} / \mathrm{ha}$ to determine which combination of date and rate of application would effectively decrease number of floral stems and yet increase forage quality. Caucasian was grown on a Pratt fine sandy loam (Thermic Pasammentic Haplustalfs) soil $6 \mathrm{~km}$ north of Fort Supply, Okla. Plots (1.5 by $5 \mathrm{~m}$ ) were replicated 4 times in a randomized complete block design with a factorial treatment arrangement. Forage was harvested above a $6-\mathrm{cm}$ stubble height in late July. On the control plots, the in vitro dry matter digestibility (IVDMD) and crude protein of leaves was 6.5 and 2.0 percentage units higher than stems. Leaves accounted for $40 \%$ of the forage yield the first year and $64 \%$ the second year. Mefluidide was most effective if applied late May. Response surface analysis showed that mefluidide $(0.56 \mathrm{~kg} / \mathrm{ha})$ application in late May decreased number of floral stems 35 to $50 \%$, forage yields 20 to $25 \%$, and leaf yields 7 to $25 \%$. In 1985, mefluidide had no effect on IVDMD and crude protein of leaves, stems, and whole plants. In 1986, application of $0.56 \mathrm{~kg} / \mathrm{ha}$ mefluidide in late May increased leaf, stem, and whole plant IVDMD by $1.2,2.7$, and 2.0 percentage units and crude protein by 0.5 to 1 percentage units. Mefluidide did not decrease number of floral stems enough nor increase leaf yield and forage quality enough to be economically used on Caucasian to improve livestock gain during late July.

Key Words: Bothriochloa caucasica, Old World bluestem, crude protein, in vitro dry matter digestibility, application dates, application rates

'Caucasian' bluestem [ Bothriochloa caucasica(Trin.) C.E. Hubb.] provides high quality forage during the early summer but growth of floral stems causes a rapid decline in forage quality from mid to late summer. If the number of flora stems in Caucasian could be reduced it should improve forage quality. Dabo et al. (1987) reported that in vitro dry matter digestibility (IVDMD) of leaves and stems of Caucasian was about equal when averaged over 10 weekly sampling dates during the first growing season, but IVDMD of stems was 3 percentage units less than that of leaves when averaged over 10 weekly sampling dates during the second growing season. Even if IVDMD of leaves and stems was similar, this does not make them equal in nutritional quality. Minson (1972) and Laredo and Minson (1973) found that intake of leaves by sheep was $59 \%$ greater than that of stems even when digestibility of both was similar.

Application of mefluidide [N-(2,4-dimethyl-5-\{[(trifluoromethyl)sulfonyl]amino\}phenyl)acetamide], a growth regulator, has effectively reduced floral stems of a number of grasses. Mefluidide application to crested wheatgrass [Agropyron desertorum (Fisch.)

\footnotetext{
Author is range scientist, USDA-ARS, Southern Plains Range Research Station, 2000-18th St., Woodward, Okla. 73801.

This article is a contribution from USDA, Agricultural Research Service.

Manuscript accepted 19 July 1989.
}

Schult.] at or near floral primordium initiation decreased forage yield by 20 to $60 \%$, but increased digestibility 2 to 5 percentage units (Haferkamp et al. 1987, White 1989). Mefluidide application to smooth brome (Bromus inermis Leyss.) (Wimer et al. 1986) in Nebraska decreased forage yield about $60 \%$ throughout the summer but still increased animal weight gains/ha. Under more mesic conditions, application of mefluidide decreased forage yield of tall fescue (Festuca arundinacea Schreb.) (Glenn e al. 1980, Robb et al. 1983, Lomas and Moyer 1985, Garrett et al. 1986), and bermudagrass [Cynodon dactylon (L.) Pers. var. dactylon] (DeRamus and Bagley 1984) for a few weeks yet increased animal weight gains.

The objective of this study was to determine the effects of 3 dates (late May, early June, and mid June) and 4 rates $(0.00,0.28,0.56$, and $0.84 \mathrm{~kg} / \mathrm{ha}$ ) of mefluidide application on number of floral stems, forage yield, leaf percentage, IVDMD, and crude protein of leaves and stems of Caucasian bluestem.

\section{Materials and Methods}

The study was conducted during 1985 and 1986 on a wellestablished Caucasian bluestem pasture originally seeded in 1958 . The study site was located $6 \mathrm{~km}$ north of Fort Supply, Okla., at an elevation of $655 \mathrm{~m}$ on a Pratt fine sandy loam soil (Thermic Pasammentic Haplustalfs). The soil, however, is a variant because of discontinuity to loamy substrate at 1 to $2 \mathrm{~m}$ below the surface. The previous year's vegetation was burned each spring when Caucasian started growth during April. After burning, the site was fertilized each year with urea at $67 \mathrm{~kg} \mathrm{~N} /$ ha.

Average annual precipitation for 44 years was $563 \mathrm{~mm}$, with 16 , 13,40 , and $31 \%$ of it received from October through December, January through March, April through June, and July through September, respectively. Precipitation was $500 \mathrm{~mm}$ from October 1984 through June 1985 and was 196,120 , and $108 \%$ of normal for October through December, January through March, and April through June, respectively. Precipitation was $410 \mathrm{~mm}$ from October 1985 through June 1986 and was 224, 24, and 89\% of normal for October through December, January through March, and April through June, respectively. January and July long-term mean temperatures are 2 and $28^{\circ} \mathrm{C}$, respectively, and the average frost-free period is 177 days.

In 1985 and 1986, mefluidide was applied in a $3 \times 4$ factorial with 3 application dates and 4 application rates $(0.00,0.28,0.56$, and $0.84 \mathrm{~kg} / \mathrm{ha}$ of active ingredient) to a new set of plots each application date. Plots $(1.5$ by $5.0 \mathrm{~m}$ ) were replicated 4 times in a randomized complete block design. Mefluidide was applied 28 May, 3 June, and 14 June 1985 and 30 May, 4 June, and 11 June 1986. Two hours after the 3 June 1985 mefluidide application, it rained $20 \mathrm{~mm}$ and another $19 \mathrm{~mm}$ was received the next day. Therefore it was assumed that mefluidide had been washed off the plant leaves and a second application was made 7 June 1985 on the same plots. Mefluidide was applied in $190 \mathrm{~L}$ water/ha using 3 flat-fan nozzles (80015) mounted on a bicycle sprayer pressurized with a $\mathrm{CO}_{2}$ at 207 $\mathrm{kPa}$ and traveling at $3.2 \mathrm{~km} / \mathrm{hr}$.

The number of floral stems were counted each year during late 
Table 1. Probability of $F$ test for linear, quadratic, and cubic treatment responses to 3 application dates and 4 rates of mefluidide $(0,0.28,0.56$, and $0.84 \mathrm{~kg} / \mathrm{ha}$ ) on number of floral stems, forage yield, leaf percentage, and leaf yield of Caucasian bluestem grown near Fort Supply, Okla. during 1985 and 1986.

\begin{tabular}{|c|c|c|c|c|c|c|c|c|}
\hline & \multicolumn{2}{|c|}{$\begin{array}{l}\text { Floral } \\
\text { stems }\end{array}$} & \multicolumn{2}{|c|}{$\begin{array}{c}\text { Forage } \\
\text { yield }\end{array}$} & \multicolumn{2}{|c|}{$\begin{array}{c}\text { Leaf } \\
\text { percent }\end{array}$} & \multicolumn{2}{|c|}{$\begin{array}{l}\text { Leaf } \\
\text { yield } \\
\end{array}$} \\
\hline & 85 & 86 & 85 & 86 & 85 & 86 & 85 & 86 \\
\hline Reps & 0.72 & 0.04 & 0.38 & 0.01 & 0.37 & 0.05 & 0.79 & 0.07 \\
\hline$D_{1}$ & 0.51 & 0.84 & 0.10 & 0.20 & 0.56 & 0.98 & 0.55 & 0.17 \\
\hline $\mathrm{D}_{\mathrm{q}}$ & $<0.01$ & 0.03 & 0.05 & 0.30 & 0.39 & 0.30 & 0.02 & 0.55 \\
\hline $\mathbf{R}_{1}$ & $<0.01$ & $<0.01$ & $<0.01$ & $<0.01$ & 0.94 & $<0.01$ & $<0.01$ & 0.03 \\
\hline $\mathbf{R}_{\mathbf{q}}$ & 0.77 & 0.60 & 0.91 & 0.55 & 0.74 & 0.22 & 0.89 & 0.21 \\
\hline & 0.22 & 0.30 & 0.16 & 0.70 & 0.30 & 0.22 & 0.83 & 0.97 \\
\hline DXR & 0.20 & 0.10 & 0.02 & 0.01 & 0.48 & 0.08 & 0.13 & 0.03 \\
\hline $\mathrm{D}_{1} \mathbf{X R}_{1}$ & 0.16 & 0.21 & 0.75 & 0.01 & 0.53 & 0.58 & 0.41 & 0.02 \\
\hline $\mathbf{D}_{1} \times \mathbf{R}_{\mathbf{q}}$ & 0.52 & 0.16 & 0.94 & 0.10 & 0.20 & 0.70 & 0.31 & 0.08 \\
\hline $\mathbf{D}_{1} \mathbf{X} \mathbf{R}_{\mathbf{c}}$ & 0.32 & 0.03 & 0.06 & 0.14 & 0.97 & $<0.01$ & 0.13 & 0.68 \\
\hline$D_{q} \times R_{1}$ & 0.05 & 0.80 & $<0.01$ & 0.55 & 0.37 & 0.52 & 0.02 & 0.56 \\
\hline$D_{q} \times R_{q}$ & 0.23 & 0.26 & 0.77 & 0.98 & 0.18 & 0.15 & 0.35 & 0.66 \\
\hline$D_{q} X R_{c}$ & 0.85 & 0.19 & 0.66 & 0.01 & 0.35 & 0.53 & 0.92 & 0.01 \\
\hline
\end{tabular}

$D=$ date, $R=$ rate, ${ }_{1}=$ linear, $\mathrm{q}=$ quadratic, $\mathrm{c}=$ cubic response

July using 3 quadrats $(0.3$ by $0.6 \mathrm{~m}$ ) per plot. On $23 \mathrm{July} 1985$ and 31 July 1986, a 100 to 150 -g subsample (dry weight) of plant material from 4 or 5 plants was harvested from each plot and dried at $60^{\circ} \mathrm{C}$ for dry matter determination, leaf percentage, and chemical analysis. That same day forage yield was determined by harvesting a 0.86 by $5.0-\mathrm{m}$ area the first year and a 1.25 by $5.0-\mathrm{m}$ area the second year to a 6-cm stubble height.

Leaf percentage was determined by first chopping the subsample into 2 to $3-\mathrm{cm}$ lengths then separating them in a Bates ${ }^{!}$Laboratory Aspirator manufactured by Ricetown Sample Devices ${ }^{1}$ of Stuttgart, Ark. The feed dial was opened to maximum (7) and the Powerstat (variable speed control) set at 35 to 38 . The forage sample was rerun through the aspirator until all leaves were aspirated out of the stem fraction. This requires about 4 passes through the machine which can be completed in 10 to 12 minutes. The leaf and stem fractions were visually examined and additionally hand separated if required. The leaf fraction included all leaf blades and about half of leaf sheaths while the stem fraction included all stems and those leaf sheaths still attached to the stems. This method has

Trade names and company names are included for the benefit of the reader, and imply no endorsement or preferential treatment of the product by USDA. been successful for all grasses we have tested if the leaves do not roll during drying. Leaf percentage was calculated as what weight they were of the whole plant dry matter yield.

Leaf and stem fractions were ground to pass a $1-\mathrm{mm}$ screen before analysis. The IVDMD was determined by a modification of the Tilley and Terry two-stage method (White et al. 1981) and the nutrient-buffer solution was supplemented with urea. Nitrogen concentration was determined by a semimicro-Kjeldahl method (Bremner and Breitenbeck 1983) and results multiplied by 6.25 to estimate crude protein.

Data were analyzed with a $3 \times 4$ factorial analysis of variance for a randomized complete block design. Orthogonal polynomials were used to partition the date treatment sum of squares into linear and quadratic components while rate treatment sum of squares was partitioned into linear, quadratic, and cubic components. The interaction sum of squares was partitioned into all possible combinations, e.g., date quadratic by rate cubic, and significance of each was determine with an $F$ test as shown in Tables 1 and 2 (Cochran and Cox 1957). In order to 3-dimensionally plot the significant interactions identified by the analysis of variance $F$ test, the coefficients for the specific terms in orthogonal polynomial equations must be determined mathematically either in the analysis of variance procedure or with multiple regression; I chose the latter method. When more than one interaction was significant, the interaction which resulted in the highest $R^{2}$ and was biologically reasonable was used to display the response surface 3-dimensionally. If the response surface was not significant, then the linear by linear interaction was plotted to show that there was no response. For example, if the date quadratic and rate linear were significant and interaction nonsignificant, generally the $D_{q}-R_{1}$ was significant and was plotted to show how they responded together. Orthogonal polynomials developed by the Taylor series expansion are only an approximation of a production function (Heady and Dillon 1961) and often cause a response across the check treatments when none exists (Fig. 1a).

\section{Results and Discussion}

\section{Floral Stems}

Application of increasing rates $(0.00,0.28,0.56$, and $0.84 \mathrm{~kg} / \mathrm{ha})$ of mefluidide resulted in a linear decrease in floral stems of Caucasian bluestem the first year and a cubic decrease the second year (Fig. 1a,b). Application of mefluidide at $0.56 \mathrm{~kg} / \mathrm{ha}$ in late May, reduced number of floral stems $35 \%$ in 1985 and $50 \%$ in 1986 . In 1985 , it is not known whether precipitation received within 2 hours

Table 2. Probability of $\mathrm{F}$ test for linear, quadratic, and cubic treatment responses to 3 application dates and 4 rates of mefluidide $(0,0.28,0.56$, and 0.84 $\mathrm{kg} / \mathrm{ha}$ ) on leaf, stem, and whole plant IVDMD and crude protein of Caucasian bluestem grown near Fort Supply, Okla. during 1985 and 1986.

\begin{tabular}{|c|c|c|c|c|c|c|c|c|c|c|c|c|}
\hline & \multicolumn{6}{|c|}{ IVDMD } & \multicolumn{6}{|c|}{ Crude Protein } \\
\hline & \multicolumn{2}{|c|}{ leaf } & \multicolumn{2}{|c|}{ stem } & \multicolumn{2}{|c|}{ whole } & \multicolumn{2}{|c|}{ leaf } & \multicolumn{2}{|c|}{ stem } & \multicolumn{2}{|c|}{ whole } \\
\hline & 85 & 86 & 85 & 86 & 85 & 86 & 85 & 86 & 85 & 86 & 85 & 86 \\
\hline Reps & 0.52 & 0.37 & 0.57 & $<0.01$ & 0.52 & 0.01 & 0.82 & $<0.01$ & 0.48 & $<0.01$ & 0.67 & $<0.01$ \\
\hline $\mathrm{D}_{1}$ & 0.88 & 0.99 & 0.28 & 0.10 & 0.47 & 0.40 & 0.17 & 0.10 & 0.75 & 0.60 & 0.49 & 0.21 \\
\hline$D_{q}$ & $<0.01$ & 0.99 & 0.05 & 0.68 & 0.01 & 0.97 & 0.44 & 0.37 & 0.09 & 0.41 & 0.12 & 0.69 \\
\hline $\mathbf{R}_{1}$ & 0.29 & $<0.01$ & 0.25 & $<0.01$ & 0.27 & $<0.01$ & 0.14 & $<0.01$ & 0.27 & $<0.01$ & 0.18 & $<0.01$ \\
\hline $\mathbf{R}_{\mathbf{q}}$ & 0.59 & 0.89 & 0.60 & 0.65 & 0.78 & 0.99 & 0.18 & 0.38 & 0.72 & 0.51 & 0.50 & 0.43 \\
\hline $\mathbf{R}_{\mathbf{c}}$ & 0.12 & 0.59 & 0.27 & 0.63 & 0.13 & 0.41 & 0.42 & 0.04 & 0.48 & 0.23 & 0.36 & 0.09 \\
\hline DXR & 0.83 & 0.44 & 0.60 & 0.14 & 0.57 & 0.12 & 0.43 & $<0.01$ & 0.40 & 0.35 & 0.33 & $<0.01$ \\
\hline $\mathrm{D}_{1} \mathrm{XR}_{1}$ & 0.48 & 0.14 & 0.57 & 0.09 & 0.46 & 0.07 & 0.16 & 0.10 & 0.14 & 0.20 & 0.11 & 0.05 \\
\hline$D_{1} X_{R}$ & 0.23 & 0.27 & 0.82 & 0.10 & 0.51 & 0.14 & 0.92 & 0.46 & 0.55 & 0.66 & 0.95 & 0.83 \\
\hline$D_{1} \times R_{c}$ & 0.99 & 0.56 & 0.40 & 0.58 & 0.57 & 0.20 & 0.84 & 0.01 & 0.31 & 0.34 & 0.54 & 0.01 \\
\hline$D_{q} \times R_{1}$ & 0.81 & 0.20 & 0.79 & 0.70 & 0.92 & 0.24 & 0.47 & $<0.01$ & 0.96 & 0.09 & 0.57 & $<0.01$ \\
\hline$D_{q} \times R_{q}$ & 0.66 & 0.52 & 0.70 & 0.53 & 0.80 & 0.59 & 0.72 & 0.53 & 0.38 & 0.52 & 0.98 & 0.33 \\
\hline$D_{q} X R_{c}$ & 0.47 & 0.71 & 0.08 & 0.07 & 0.07 & 0.21 & 0.08 & 0.15 & 0.18 & 0.47 & 0.06 & 0.14 \\
\hline
\end{tabular}



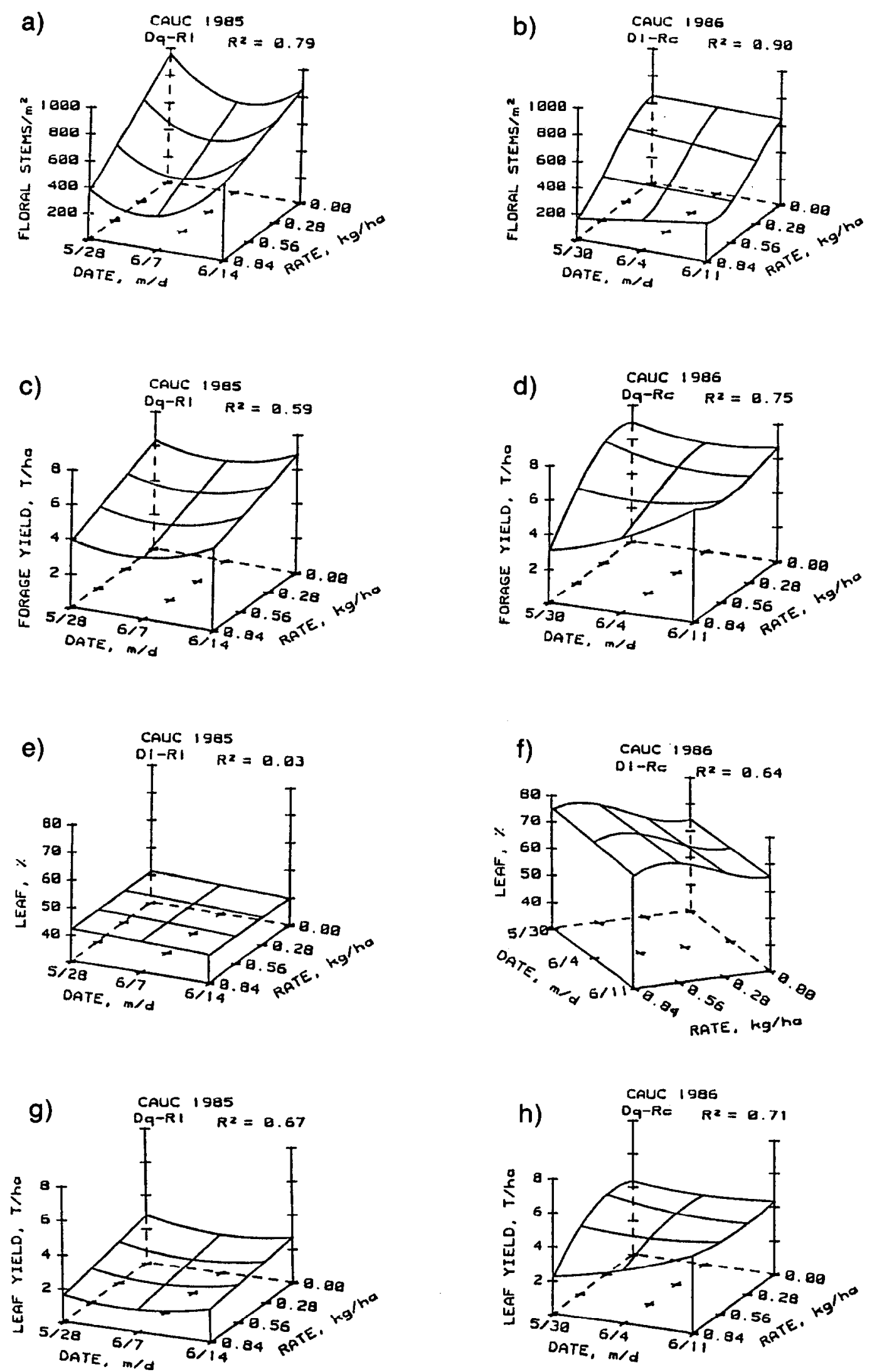

Fig. 1. Effects of date and rate of mefluidide application on floral stems (a \& b), forage yield (c \& d), leaf percentage (e \& $\mathrm{n}$ ), and leaf yield ( $\&$ h) of Caucasian bluestem harvested in late July 1985 and 1986 near Fort Supply, Okla. 
Table 3. Effect of $0.00,0.28,0.56$, and $0.84 \mathrm{~kg} / \mathrm{ha}$ of mefluidide on leaf, stem, and whole plant IVDMD and crude protein of Caucasian bluestem in 1985 and 1986 when averaged over 3 application dates.

\begin{tabular}{|c|c|c|c|c|c|c|c|c|c|c|c|c|}
\hline \multirow{3}{*}{$\begin{array}{l}\text { Mefl. } \\
\text { Rate }\end{array}$} & \multicolumn{6}{|c|}{ IVDMD } & \multicolumn{6}{|c|}{ Crude Protein } \\
\hline & \multicolumn{2}{|c|}{ leaf } & \multicolumn{2}{|c|}{ stem } & \multicolumn{2}{|c|}{ whole } & \multicolumn{2}{|c|}{ leaf } & \multicolumn{2}{|c|}{ stem } & \multicolumn{2}{|c|}{ whole } \\
\hline & 85 & 86 & 85 & 86 & 85 & 86 & 85 & 86 & 85 & 86 & 85 & 86 \\
\hline $\mathrm{kg} / \mathrm{ha}$ & & & & & & & $0-1$ & & & & & - \\
\hline 0.00 & 58.2 & 53.0 & 51.4 & 46.6 & 54.2 & 50.7 & 6.4 & 5.2 & 4.4 & 3.3 & 5.2 & 4.5 \\
\hline 0.28 & 59.4 & 54.0 & 52.2 & 47.9 & 55.2 & 52.1 & 6.9 & 6.0 & 4.7 & 3.7 & 5.6 & 5.3 \\
\hline 0.56 & 58.6 & 54.1 & 51.4 & 48.3 & 54.2 & 52.5 & 6.8 & 5.7 & 4.7 & 3.6 & 5.5 & 5.2 \\
\hline 0.84 & 59.3 & 55.0 & 53.0 & 51.0 & 55.6 & 53.9 & 6.8 & 6.2 & 4.8 & 4.4 & 5.7 & 5.7 \\
\hline SE & 0.5 & 0.4 & 0.8 & 0.8 & 0.6 & 0.5 & 0.2 & 0.2 & 0.2 & 0.2 & 0.2 & 0.2 \\
\hline Sig. & ns & $\mathrm{R}_{1}$ & ns & $\mathbf{R}_{1}$ & ns & $\mathrm{R}_{1}$ & ns & $\mathrm{D}_{\mathrm{q}} \mathrm{R}_{1}$ & ns & $R_{1}$ & ns & $D_{q} R_{1}$ \\
\hline
\end{tabular}

$\mathrm{R}=$ rates, $\mathrm{D}=$ dates, $\mathrm{I}=$ linear, $\mathrm{a}$ =quadratic

of the early June application negated the effect of mefluidide on floral stems since a second application of mefluidide was made 4 days later. Application of $0.56 \mathrm{~kg} / \mathrm{ha}$ of mefluidide in mid June reduced floral stems of Caucasian 20\% in 1985 and $50 \%$ in 1986.

Mefluidide reduced number of floral stems of Caucasian bluestem far less than the $90 \%$ reported for crested wheatgrass (Haferkamp et al. 1987, White 1989). Mefluidide was most effective in reducing number of flora stems of crested wheatgrass when applied within 2 weeks after the majority of the floral primordium had formed (White 1989). Floral primordium of crested wheatgrass form some time during April depending upon the year (White 1989). Mefluidide applied before floral primordium initiation of a tiller does not abort development of that floral stem. Proper timing of mefluidide application on Caucasian was difficult because floral primordium initiation occurred over a long period. Floral primordium initiation of crested wheatgrass, however, was limited to about a 2-week period.

\section{Forage Yield}

Increasing mefluidide rates resulted in a linear decrease in forage yield the first year and a cubic decrease the second year (Fig. Ic,d). The application of $0.56 \mathrm{~kg} / \mathrm{ha}$ mefluidide in late May both years reduced forage yield 28 to $18 \%$ while application in mid June reduced yields only 16 and $12 \%$ the first and second years when compared with the control. In 1985, it is not known whether precipitation received within 2 hours of the early June application negated the effect of mefluidide on forage yield since a second application was made 4 days later. Forage yield reduction by mefluidide was similar to that reported for crested wheatgrass (Haferkamp et al. 1987, White 1989) but less than that reported for smooth brome (Wimer et al. 1986).

\section{Leaf Percentage}

Application of mefluidide in 1985 had no effect on leaf percentage (Fig. le). In 1986, increasing mefluidide rates resulted in a cubic increase in leaf percentage with the $0.56 \mathrm{~kg} /$ ha rate being the most effective (Fig. 1f). In 1986, application of $0.56 \mathrm{~kg} / \mathrm{ha}$ of mefluidide increased the leaf percentage 10 units on all 3 dates.

Leaf percentage on control plots was $40 \%$ the first year compared to $64 \%$ the second year. Drought conditions the preceding 2 years may have affected leaf percentage in 1985 . Following precipitation during July and August 1983 plus unusually cold temperature during December 1983, some Caucasian plants adjacent to the study site died in the spring 1984. During 1984, April through September precipitation was only $40 \%$ of normal.

\section{Leaf Yield}

Leaf yield on the control plots was almost twice as much in 1986 (4.2 T/ha) as in 1985 (2.5 T/ ha) (Fig. 1g,h) even though total forage yield was similar both years (Fig. Ic,d). In 1985, the application of mefluidide $(0.56 \mathrm{~kg} / \mathrm{ha})$ in late May or mid June reduced leaf yield 20 and $15 \%$, respectively. In 1986, the application of mefluidide
$(0.56 \mathrm{~kg} / \mathrm{ha})$, in late May, early June, and mid June reduced leaf yields 7,10 , and $0 \%$, respectively. In 1985 , it is not known if precipitation received within 2 hours of early June application negated the effect of mefluidide on leaf yield since a second application was made 4 days later.

\section{IVDMD}

Year effects seemed to have a greater influence on leaf yield (Fig. 1g,h) and IVDMD (Table 3) than did mefluidide. Nearly double the leaf yield in 1986 but similar total forage yield was associated with 5,5 , and 3.5 percentage units less leaf, stem, and whole plant IVDMD. On the control plots, stem IVDMD averaged 6.8 and 6.4 percentage units less than that of leaves the first and second years. These differences in IVDMD between leaves and stems is far greater than that reported by Dabo et al. (1987) for Caucasian grown near Stillwater, Okla. Whole plant IVDMD averaged 54\% and $51 \%$ the first and second years, respectively.

In 1985, increasing mefluidide rates had no effect on leaf, stem, or whole plant IVDMD (Table 3). In 1986, increasing mefluidide rates resulted in a linear increase in leaf, stem, and whole plant IVDMD on all application dates. Application of $0.56 \mathrm{~kg} / \mathrm{ha}$ of mefluidide increased leaf, stem, and whole plant IVDMD 1.2, 2.7, and 2.0 percentage units, respectively. This is similar to the 2 to 5 percentage units that mefluidide increased whole plant IVDMD of crested wheatgrass (Haferkamp et al. 1987, White 1989). The 1.2 percentage units that mefluidide increased leaf IVDMD in 1986 probably would not offset the 7 to $10 \%$ reduction in leaf yield to increase beef gains/ha.

\section{Crude Protein}

Crude protein of leaves, stems, and whole plants in 1986 was less than in 1985 even though forage yield was similar both years (Table 3). Even crude protein in the leaves was not adequate for maintenance of breeding animals (NRC 1984). Crude protein in the stems averaged 2 and 1.9 percentage units less than that in the leaves.

In 1985, increasing mefluidide rates had no effect on leaf, stem, or whole plant crude protein (Table 3). In 1986, increasing rates of mefluidide resulted in a linear increase in leaf, stem, and whole plant crude protein on all application dates. Application of 0.56 $\mathrm{kg} / \mathrm{ha}$ of mefluidide increased crude protein of leaves and whole plant more if applied in late May than in early or mid June. In general, application of $0.56 \mathrm{~kg} / \mathrm{ha}$ of mefluidide increased leaf, stem, and whole plant crude protein 0.5 to 1 percentage units.

In summary, since Caucasian bluestem develops floral primordium over a long period, it makes the use of growth regulators such as mefluidide difficult and less effective than with grasses that develop floral primordium over a short period such as crested wheatgrass. Since floral primordium development patterns of grasses such as Caucasian bluestem vary with accumulated degree days and seasonal precipitation, stem yield reductions and leaf percentage increases were influenced to a greater extent by yearly climatic fluctuations. 


\section{Literature Cited}

Bremner, J.M., and G.A. Breitenbeck. 1983. A simple method for determination of ammonium in semimicro-Kjeldahl analysis of soils and plant materials using a block digester. Commun. in Soil Sci. Plant Anal. 14:905-913.

Cochran, W.G., and G.M. Cox. 1957. Factorial experiments. p. 148-182. In: Experimental designs. 2th ed. John Wiley \& Sons, New York.

Dabo, S.M., C.M. Taliaferro, S.W. Coleman, F.P. Horn, and P.L. Claypool. 1987. Yield and digestibility of Old World bluestem grasses as affected by cultivar, plant part, and maturity. J. Range Manage. 40:10-15.

DeRamus, H.A., and C.P. Bagley. 1984. The effect of mefluidide treatment on bahia and bermudagrass and nutrient utilization. p. 152-156. In: Forage systems-leading U.S. agriculture into the future. Amer. For. Grassl. Counc. 23-26 Jan. 1984, Houston, Texas.

Garrett, J.L., D.G. Ely, and D.K. Aaron. 1986. Embark treatment of fertilized Kentucky 31 tall fescue pastures for yearling cattle. J. Anim. Sci. 63(Suppl.1):294-295.

Glenn, S., C.E. Rieck, D.G. Ely, and L.P. Bush. 1980. Quality of tall fescue forage affected by mefluidide. J. Agr. Food Chem. 28:391-393.

Haferkamp, M.R., R.F. Miller, and F.A. Sneva. 1987. Mefluidide effects on forage quality of crested wheatgrass. Agron. J. 79:637-641.

Heady, E.O., and J.L. Dillon. 1961. Agricultural production functions. Iowa State Univ. Press, Ames, Iowa.
Laredo, M.A., and D.J. Minson. 1973. The voluntary intake, digestibility, and retention time by sheep of leaf and stem fractions of five grasses. Aust. J. Agr. Res. 24:875-888.

Lomas, L.W., and J.L. Moyer. 1985. Effect of treating tall fescue pasture with mefluidide on performance of grazing steers. J. Anim. Sci. 61(Suppl.1):342.

Minson, D.J. 1972. The digestibility and voluntary intake by sheep of six tropical grasses. Aust. J. Exp. Agr. Anim. Husb. 12:21-27.

NRC. 1984. Nutrient requirements of domestic animals, No. 1. Nutrient requirements of beef cattle. 6th revised ed. Nat. Acad. Sci-Nat. Res. Counc. Washington, D.C.

Robb, T.W., D.G. Ely, C.E. Rieck, S. Glenn, L. Kitchen, B.P. Glenn, and R.J. Thomas. 1983. Beef production from tall fescue treated with mefluidide, a chemical plant-growth regulator. p. 725-728. In.J.A. Smith and V.W. Hays (eds.) Proc. XIV Int. Grassl. Congr., 15-24 June 1981, Lexington, $\mathrm{Ky}$.

White, L.M., G.P. Hartman, and J.W. Bergman. 1981. In vitro digestibility, crude protein, and phosphorus content of straw of winter wheat, spring wheat, barley, and oat cultivars in eastern Montana. Agron. J. 73:117-121.

White, L.M. 1989. Growth regulators effect on crested wheatgrass forage yield and quality. J. Range Manage. 42:46-50.

Wimer, S.K., J.K. Ward, B.E. Anderson, and S.S. Waller. 1986. Mefluidide effects on smooth brome composition and grazing cow-calf performance. J. Anim. Sci. 63:1054-1062.

\section{New Editor for $\boldsymbol{J R M}$}

Gary Frasier took over editorship of the Journal of Range Management on April 1, replacing Patricia G. Smith. Frasier served on the editorial board of the Journal 1980-1984. He has been editor of Rangelands since 1984 and will continue in that capacity with the added responsibility for the Journal.

Dr. Smith has reduced her work schedule to half time and will continue as Production Editor of the Society's magazines. She was editor of the Journal of Range Management from March 1982 until April 1990.

Manuscripts and other editorial correspondence should be sent to the editor at 780 West Cool Drive, Tucson, Arizona 85704. Page proofs should still be returned to the production editor at Society for Range Management, 1839 York St., Denver, Colorado 80206. 